\title{
Isayev R.A.*
}

DOI: 10.25108/2304-1730-1749.iolr.2016.47.43-78

\section{Problems of sources' search of criminalistically significant information}

\begin{abstract}
Criminalistical methods of sources' search of criminalistical information are the scientific substantiated checked by the practice and justifying aim-directed ways of actions that are applied in compliance with requirements of legality and ethic norms directed at discovering of the sources of criminalistical information.

While searching the sources of criminalistical information, achievements of science and experience might be used consciously with application of the logical techniques or intuitively in result of quick intermittent, almost involuntary, activity of conscience and subconscious. Wide experience and knowledge always lies in basis of intuition.
\end{abstract}

Keywords: criminalistical information; source; tactical technique; technical means; criminalistical method.

Search of the sources of criminalistical information is basic stage all activity on investigation of crimes. The base of a search is a complex of investigative and operation searching actions, interlinked with searching activity of state bodies, public institutions and population, performed, as rule, on instruction of an investigator and inquiry body or own initiative. Theoretical basis of a search is scientific knowledge about regularities of reflection's processes, provisions of sociology and psychology $[1,4,5]$.

\footnotetext{
- Isayev Rashad Abdulla oglu - PhD in Law, a counselor of the Ministry of Justice (Azerbaijan). Email: mopi_sid@yahoo.com
} 
Searching of the sources of criminalistical information carried out with using of a system of tactical techniques, nature of which depends on searching object, circumstances of crime, content of primary information about occurrence.

There is distinguished non-procedural and procedural, forms of searching criminalistical information's sources. Questioning of population, using of materials of various records, performance of private operational searching measures are the non-procedural forms. Procedural and non-procedural forms of searching of criminalistical information mutually supplement each other [12, p. 96-97].

Information received from non-procedural sources may contain data concerning possible sources of criminalistical information, their disposition and characteristic features, probable behaviour of process' participants, nature of information, which might be obtained through research that or other sources.

Criminalistical information that received from non-procedural sources has orienting nature, but it does not belittle its significance in prevention and suppression of criminal activity, and also in choice of more reasonable tactical and technical measures in course of searching of new sources of information.

Some sources of criminalistical information come in view of investigator or inquiry officer during his investigative work on disclosing crime. But, in all cases discover of them requires purposeful, hard work, using own experience for disclose of similar crimes, studying of the way of commission of investigated crime with considering of imaginative reconstruction of occurrence's circumstances, typical investigative situations and versions.

Criminalistical methods of search of criminalistical information's sources are scientifically substantiated, tested with practice and justifying themselves ways of action, which are applied in compliance with requirements of law and ethic norms, directed to discover of the sources of criminalistical information.

At searching of the sources of criminalistical information achievements of science and experience might be used consciously with application of logical techniques, or intuitively in result of quick, step-like almost involuntary activity of 
conscious and subconscious. Big experience and knowledge always lay in the basis of intuition.

Studying of primary data, commission of logical operations and application of heuristic methods at searching of the sources of criminalistical information are forming imaginative model of the way of commission and concealment of crime, in which is integrated a system of occurrence's ideas, interaction of objects and persons in course of preparation, commission of crime and concealment its traces. This model allows assuming on necessity or possibility appearance in some places of certain sources of criminalistical information or on those, existence of which contradicts created ideal model. Detection of indicated sources either confirm or exclude rightness of hypothesis, gives an opportunity to forecast finding other sources of information in other place and thereby it creates the terms for systematic purposeful searching of the new sources [15, p. 66-68].

Imaginative searching model might be not only figurative but also symbolic one if it designed with using of that or other symbolic system.

An author has been developed a model of searching of criminalistical information that based on designing of informational field through provisions of games' theory.

For that, all criminalistical information has conditionally divided into information on subject (1), an object of criminal encroachment (2), time (3), occurrence of crime (4), way of commission (5) and consequences of criminal actions (6). In addition, in the model is separated outside information, which has no criminalistical significance (0).

Informational field of crime presents contiguous cells of certain information that according to content marked from no. 0 to no. 6. Contacting of information of the two cells is forming informational juncture.

Research made allows asserting that informational streams form informational field in certain regularity of informational junctures, which are established only at contacting of similar criminalistical information. 
It means that for example, in all sources the criminalistical information, conditionally marked by no. 5 will be neighboured (joined) only with analogical no. 5 , no. 6 to no. 6 , no. 1 to no. 1 etc.

In turn, stated determines developed by the author the technique of search of criminalistical information.

Let's consider foregoing at concrete sample. On 10 January 1998 about 8 o'clock in the yard of house no. 6 in Magomayev Street was found a corpse of man with traces of gunshot wound in a head.

At inspection of incident occurrence there was found a cartridge case of gun 9 $\mathrm{mm}$ (5) and handkerchief with stains of blood (6).

In course of investigation of criminal case, instituted on this fact, there were conducted the following actions and received information that was divided according to developed technique on significance into the six groups:

1. There were interrogated the residents of home no. 6 on Magomayev Street and employees of trading facilities and other institutions located close to occurrence of incident:

- dead person was identified as a guard of kindergarten located in the yard of the house (1);

- heard sound of shot about 7 o'clock morning $(3,4,5)$;

- dead person abused with alcohol drinking and often kicked up a shindy (2);

2. It was conducted a complex medical biological trace expert examination:

- death occurred from gunshot wound in a head approximately before one hour till victim's detection $(2,3,4,5,6)$;

- blood on the handkerchief does not belong to the victim (1);

- gunshot wound in a head caused with $9 \mathrm{~mm}$ bullet that stuck in skull of the $\operatorname{victim}(4,5,6)$;

3. It was conducted ballistic expert examination:

- bullet found in the skull was in cartridge that discovered in occurrence (5);

4. Interrogated a spouse and relatives of the victim:

- in evening victim was sought on telephone by his friend A. (1 or 0$)$ : 


\section{Interrogated citizen A.:}

- the victim was seen the last time one week before incident ( 0 or 1$)$;

6. It was conducted biological expert examination concerning the handkerchief:

- blood of A. and blood on the handkerchief is the same group (1);

7. Questioned close friends of the victim:

- A. borrowed to the victim big amount of money (1);

8. It was interrogated employees of kindergarten:

- on eve A came to kindergarten and looked for the victim (1);

- A was very anxious (1);

9. Conducted confrontation between relatives of the victim and employees of the kindergarten from one side and $\mathrm{A}$ - from other side:

- A. admitted that he looked for the victim in concerning the debt but he denied the murder (1);

10. Conducted search in country house of A.:

- detected a gun PM $(1,5,6)$;

11. Performed ballistic expert examination:

- bullet and cartridge were used in the gun found to A. $(1,2,5,6)$;

12. A. detained and questioned as suspected:

- he told the reasons and circumstances of committed crime $(1,2,3,4,5,6)$.

In course of investigation there were also conducted other actions but information received had not had criminalistical significance (0).

The results of investigative actions allow concluding that junctures of criminalistical information let conduct its purposeful searching.

Search of sources of criminalistical information is carried out not only through ideal, but also material models, which presented to be really existed items and are in some sense of analog of the items-originals. As rule, material models are selected from number of analog or produced. Sometimes there reconstructed the objects. Designing of the models or reconstructions, as rule, associated with classification of the items i.e. with determination its type and class, kind or form. 
Material models can be produced by experts in the basis of studying of identifying objects.

Choice of tactical techniques and technical means of search of the sources of criminalistical information is determined by knowledge of the regularities of processes of formation and transformation of information. These are psychological regularities of testimonies' formation, regularities of trace-formation and other changes reflecting significant for investigation facts.

Private criminalistical techniques of searching of the sources of criminalistical information linked with usage of some technical means and ways. From point of view of searching technique, material carriers of criminalistical information might be classified into visible and invisible with eye. For detection o the latter, there should be applied certain technical means and ways $[13 ; 14 ; 16]$.

Speaking on search of criminalistical information, it is necessary to note that law ties the institution of criminal case and whole subsequent production on it to discovering of the signs of crime (Art. 46 of the CCP), which might be related to any element of corpus delicti, but typically they correlated with the ways of commission and concealment of crime.

There is existed mutual connection between signs of crime and the way of its commission: on signs are judged about the way, knowledge of the way is allowed maximum fully to find the signs of its application and through both the way and signs discover whole occurrence [11, p. 111-113].

Signs of crime might be found with several ways. First, they are found with conducting of operational searching measures that is preceded of institution of criminal case. Second, they might be discovered by citizens and also representatives of various organizations and enterprises at conducting of checking and inspecting works etc. third, they are found by an investigator, prosecutor and court. In the most cases, data about the signs of crime is in a list of those primary information, which an investigator or inquiry body have to the moment of institution of criminal case and beginning of investigation. 
An important fact in detection of crime's signs is operational searching measures, timely receipt of reliable and complete operational information.

Receiving of information that significant for prevention and disclosure of criminal activity is eventually an aim of any operational searching measure, which is testified with a list of operational searching measures.

According to Article 137 of the Code of Criminal Procedure of Azerbaijan Republic, material obtained as a result of a search operation is obtained as evidence for the prosecution if they received in accordance with the Law of Azerbaijan Republic "On search operations" and is presented and verified in order established by this Code.

Any information that received with other was is non-procedural, but it should be taken in account that not all non-procedural information received in course of operation search is operational one. Apart from operational to non-operational information are related the following: data received by subjects of proving with violations of law requirements' or in result of actions not providing by the law; information about crime received by citizens, organizations, enterprises including various technical means, traps etc; information gathered by private detective agencies, guard, expert and other legal firms [17, p. 66-68].

According to R.S. Belkin, the following are related to possible variants of using of operational information in proving as result of operation searching activity:

1. Operation information that orientates an investigator about actions and behaviour of persons involved to occurrence investigated:

- information about criminal activity of suspected and accused;

- information about actions of various persons on concealment of committed crimes;

- information about actions or intentions to commit acts contracting investigation;

- information about persons-carriers of indicated information and material items that can be a source of this data. Usage of this information in proving is 
possible by the two ways: directly and indirectly, with transformation of the source of operation of information in source of evidence.

2. Operation information orientating of investigator about dislocation of the objects having significance for the case. This information is used:

- at adoption of decision about search, seizure, arrest of property, arrest of correspondence etc.

- for production of other actions, the goal of which is to involve indicated objects in court proceedings in order to give them procedural status: investigative inspection, identification etc.

3. Operation information containing in material items and received either directly or indirectly by operation officer or with help of specialist [2, p. 403-405].

Interrogation takes a special place among the procedural forms of search of the sources of criminalistical information.

Questioning like a specific form of communication between investigator and interrogated person is to be one of the main investigatory actions that apply at search of the sources of criminalistical information.

Significance of information received at questioning like in production other investigative actions is determined from one side compliance with objective reality and relevance to investigated case and from other one - by observance of procedural form of receiving that stipulated in law.

Transmission of information during of interrogation from one person to other one leads to its mutilation but so much that individuals talking the same language would not have understood each other. Losses of information are increased at multiple-step transmission of it. So, loss of information in witness' testimonies might be happened in result of mistakes of perception and defects of sense organs of a witness, his/her inability to reproduce perceived, wrong interpretation by investigator of testimonies of interrogated person, incorrectness of record formulation and, at last, wrong understanding of the interrogation record by the judges. 
One of the main provisions of theory of information says that information cannot be increased during going through the channel of communication. At entrance (to receiver) information on volume, as rule, is less than at output (to source). Thus, investigator receives not all information that interrogated person has: some part of it remains unclaimed $[4 ; 5]$.

Transmission of information from the source to investigator may occur as in form of verbal so graphic (written) expression. These forms become objective in verbal or written speech. Moreover, the first is more important means of communication between individuals, means of transmission of information and mental impact. This circumstance has distinguished questioning as action that has more informative capacity from other means of proving.

Information is not only the words said by questioned person, but also voice, mimics, intonation, timbre, tone, appearance, manner of behaviour.

According to provisions of the theory of information, interrogation might be presented as procedural form of communication, content of which is to receive information concerning investigated case. In result of communication between investigator, prosecutor and court from one side and witness, victim, suspected, accused from other one, information is transmitted and from talker to listener and it perception by the latter. This process might be divided into the four stages: 1) to demand and obtain information from interrogated person; 2) transmission of information of questioned person to investigator; 3) comprehension information received by investigator; 4) fixation of information [9, p. 111-113].

Transmission of information from questioned person to interrogator is a simple case, and typical form of interrogation is a mutual process of transmitting of information between investigator and questioned person. Investigator puts thought task before interrogated and receives his information. At this, interrogated person comprehends it and give information in form of testimonies.

Action of investigator at conducting of questioning is formed from a number of operations: verification in personality and familiarization to interrogated person; clarification to questioned person his/her procedural rights and duties; notifying of 
witness (victim) about criminal responsibility for refusal to give testimonies or giving obviously false testimonies; clarification to suspected concerning crime in commission of which he/she suspected; hearing of the testimonies of suspected; procedural registration of course and results. Successful solution of these objectives depends on how carefully investigator has prepared to forthcoming interrogation. Preparation to question begins for investigator at time of receiving by him information about crime, a core of the case, personality of interrogated and coming to conclusion concerning necessity his/her question.

Under preparation to question is understood a combination of preliminary conducted by investigator measures with purpose of ensuring of positive results of question. They are: a) studying of case-file materials; b) studying of personality of interrogated; c) determination of sequence of interrogations and ways of summons of questioned persons; d) preparation of place of questioning and evidences, which are required for inculpation of interrogated person; e) studying by investigator of special issues, which are required certain knowledge in science, mechanics, crafts or art; f) drawing up interrogation plan.

Tactical techniques that used at questioning are unequal between each other. Number of them is not remained constant; they are variable like investigative and judicial practice.

A choice of concrete tactical technique is also determined with circumstances of questioning: conditions, in which it is conducted, stage and its situation. So, for example, in preparatory stage of interrogation tactical techniques are applied for ascertaining of personality of interrogated, establishing psychological contact to him/her, determination his/her attitude to a subject of interrogation and to persons involved in the case and at last for choice of tactics of all interrogation.

At the stage of free narration the tactical combinations are used at receiving of complete and objective testimonies. Here, there are widely used the techniques, a content of which is a remainder, detailing and refinement.

In stage of the statement of problems the tactical techniques are used in dependence on what nature has an interrogation, conflict or non-conflict one. If 
questioning has non-conflict nature the tactical techniques directed to reception of new evidential facts, on assistance to interrogated person in recalling of forgotten. The tactics of detailed questioning, tactical techniques built in associations on adjacency and contrast serve to these purposes [10, p. 66-67].

If interrogation has a conflict nature then in dependence on what evidence an investigator has, the tactical techniques might classified into the three variants: 1) at availability of evidences that completely exposure of questioned person; 2) at their insufficiency and 3) when there is suspicious that based on circumstantial evidences [21, p. 61].

If it is presence of the first variant, there should be stimulated all positive personal features of questioned person, who does not wish to give true testimonies, logically right and tactically ably presented the evidences. In case of lack of the evidences for his/her direct incrimination, there are used the techniques, which promote the formation to interrogated person the conviction in inevitability of disclosure. Here is lawful such technique as remaining of questioned person in non-acquaintance about the volume of information that investigator has. This method might successfully be applied when crime committed by a group.

Repeated question like a tactical technique is conducted after collection any not figuring earlier criminalistical information. There is no sense to conduct repeated interrogation in the same volume and evidential arguments like the first one. Accused person may understand that during this time there is no gathered any new evidences and he will be sure that he can avoid of exposure [22, p. 66-68].

In final stage, i.e. in stage of fixation of the testimonies are applied the tactical techniques that assist more full and objective record of testimonies of questioned person. The statement of control and specifying questions, suggestion to formulate thought in exact manner, to read in person a record of interrogation are related to these techniques.

While questioning the following techniques might be effective: a) keeping in silence of some circumstances that known to investigation; b) creation the conditions, at which in imagination of interrogated person appears exaggerated 
image concerning collected evidences; c) remaining in non-acquaintance of interrogated person about behaviour of other participants of criminal group in course of investigation, plans and intentions of investigator [24, p. 96-98].

Search of the sources of criminalistical information determined by the level of interaction of investigator and operation officers at crimes' investigation.

With practice of fight against criminality developed and approved, and in some part determined with orders, rules and instructions a whole number of concrete forms and methods of organization of interaction of investigator and operation officers $[6 ; 7 ; 8]$.

The first of these forms might be named an organization of urgent mutual exchange of information about committed crimes. Experience shows that practically all information and applications about crimes committed in region or town submitted by citizens and officials only to the police. Therefore, application of a term "mutual" has rather theoretical than practical nature - it might only theoretically be assumed that the first about some crime is become known an investigator and then he, is certainly, obliged to inform the police. In practice, at organization of interaction we are talking about the fact in order to establish timely information of an investigator concerning crime committed at area served by him.

This is carried out with different ways depending mainly on concrete particularities of work's organization of investigative subdivision. These are the duties of investigators in the police control room in the police departments or so named "home duties" in small investigative subdivisions; participation of investigators or a chief of investigative subdivision in daily morning ten-fifteen minutes operation meetings together operation officers and district police officers, familiarization of investigators with daily summary of operation concerning incidents for the last days etc.

All enumerated organizational measures directed towards an investigator would urgently be informed about each committed under investigation his crime in order he will be able to begin an investigation, not expecting when police conducts urgent investigative actions. 
Another form of interaction coming from subsequent is a joint visit of investigator and operation officers of the police in place of committed crime. The purpose of such visit is an inspection of the occurrence and making of joint approved measures, specific for each means and methods. Necessity of such form of interaction is determined, the first that none of even ideal drawn up record may give an investigation complete volume of information about mechanism of on investigated crime, traces left by criminal, which he can have in course of personal inspection of occurrence.

In addition, being in place of incident, investigator has an opportunity to inspect it and also fulfill a number of other urgent investigative actions, which in most cases provide the disclosure of crime. In other side, presence of an investigator at place of incident, who carries out necessary investigative actions, allows arraigning of operation police officers of parallel production of searching measures.

Significant and effective form of interaction of investigator to operation police officers is usage by them information received in result of operation-search activity of these employees. This form of interaction might be carried out as in initial stage (so named realization of information of search nature) so in course of further investigation including at preparation and conducting of some investigative actions [18; 23].

Disseminated form of interaction of investigator and operation police officers is participation of the latter in conducting by the investigator investigatory actions. Necessity of such form of interaction is explained by the two factors determining doubled character of participation of police officers in investigatory actions. The first, due to specific particularities of organizational and tactical order it is difficult or practically cannot be carried out many investigative actions by one employee investigator or police officer.

The second factor that determines necessity of performance of considered form of interaction is an opportunity and practical reasonableness execution as in course of preparation so in at once after conducting of listed investigatory actions 
entire complex of operation search measures. Despite these measures are not integral part of conducted investigative actions, but they considerably make easy their preparation, make possible a choice of favourable time and place, rational tactics their performance and sometimes allow controlling the results of their impact to accused person or other person, in respect of whom this investigatory action is conducted, to receive information allowing more objective to evaluate the results of investigatory actions [23, p. 76-78].

In process of interaction each of sides performs its functional obligations by its adherent methods: an investigator conducts only procedural, investigative actions and operation police officer - operation-search measures. Since these and others are carried out to achieve one aim - establishing of the truth on the same investigated criminal case, decisive significance has their ably, right, with other words, - optimal combination.

Objectives, solved by combination of operation search measures and investigatory actions might be divided into the three kinds.

The first, this is a receipt of, so named, "strategic" information through of which is determined direction of further investigation, are advanced versions. This information is about a core of investigated event or person who committed it.

The second, this is a receipt of, so named, "tactical" information through of which is chosen an optimal tactics of conducting of separate investigatory actions including the place, time etc. and sometimes also kind of investigative action.

The third group might be related so named "providing" or "accompanying" operation search measures that are called to give not only operation search information but also to provide a course of investigative action $[3,19,20]$.

\section{References}

1. Belkin R.S. Kriminalistika: problemy segodnyashnego dnya [Criminalistics: issues of current day]. Moscow, 2001, 240 p. 
2. Belkin R.S. Kurs kriminalistiki [Course of criminalistics]. Moscow, 1997, vol. I, 404 p.; vol. II, 463 p.; vol. III, 478 p.

3. Beloglazov E.G. Optimal'nye lineynie modeli kriminal'nykh protsessov i ikh primenenie $\mathrm{v}$ analiticheskoi razvedke [Optimal linear models of criminal processes and their application in analytical reconnaissance]. Informatizatsiya pravookhranitel'nykh system [Informational supporting of law enforcement system]. Moscow, 2000, 211 p.

4. Blumenau D.N. Informatsiya i informatsionniy servis [Information and informational service]. Leningrad, 1989, 192 p.

5. Brillyuen L. Nauka i teoriya informatsii [Science and theory of information]. Moscow, 1960, 362 p.

6. Gromov N.A., Ponomarenkov V.A., Guschin A.N., Frandifirov Y.V. Dokazatel'stva, doznanie $\mathrm{i}$ ispol'zovanie rezul'tatov ORD [Evidences, inquest and usage of results of operation activity]. Moscow, 2001, 306 p.

7. Dvoryankin S.V. Noviye informatsionnie tekhnologii obespecheniya bezopasnosti rechevoy svyazi v ORD pravookhranitel'nikh organov [New informational technologies in ensuring of voice communication in operation activity of law enforcement bodies]. Progressivnye napravleniya razvitiya radioelektronnykh kompleksov i system [Progressive directions of development of the radio-electronic complexes and systems]. Moscow, 2001, $241 \mathrm{p}$.

8. Elinsky V.I. O metodolgii nauki i ee znachenii dlya dal'neyshego sovershenstvovaniya teoreticheskikh i prikladnikh osnov ORD [On methodology of science and its significance for further improving of theoretical and practical bases of operation activity]. Aktual'nie voprosi teorii i praktiki ORD [Actual issues of theory and practices of operation activity]. Moscow, 2001, 333 p.

9. Enikeev M.N. Osnovi obschey i yuridicheskoy psikhologii [Bases of general and forensic psychology]. Moscow, 1996, 406 p.

10. Zakatov A.A. Taktika doprosa poterpevshego na predvaritel'nom sledstvii [Tactics of victim's interrogation in preliminary investigation]. Volgograd, 1978, $206 \mathrm{p}$. 
11. Zuykov G.G. Poisk po priznakam sposobov soversheniya prestupleniy [Search on signs of the ways of crime's commission]. Moscow, 1970, $228 \mathrm{p}$.

12. Kolmakov V.P. Sledstvenniy osmotr [Investigative inspection]. Moscow, 1969, $262 \mathrm{p}$.

13. Lantsman R.M. Kibernetika i kriminalisticheskaya ekspetiza pocherka [Cybernetics and criminalistical expert examination of handwriting]. Moscow, 1968, $269 \mathrm{p}$.

14. Levy A.A. Praktika primeneniya nauchno-tekhnicheskikh sredstv sledovatelyami prokuratury [Practice of application of scientific technical means by investigators of prosecutor's office]. Moscow, 1968, 292 p.

15. Luzgin P.M. Modelirovanie pri rassledovanii prestupleniy [Modeling at investigating of crimes]. Moscow, 1981, 198 p.

16. Metodologicheskie problem vzaimodeystviya obschestvennikh, estestvennykh i tekhicheskikh nauk (kollektiv avtorov) [Methodological issues of interaction of humanitarian, natural and technical sciences (collective of authors)]. Moscow, 1981, 297 p.

17. Ovchinsky A.S. Perspektivnye napravleniya informatsionnykh tekhnologiyi v profilaktke i presecheniya organizovannoi deyatel'nosti putem operativnorozysknykh meropriyatiyi i takticheskikh deistviyi [Perspective directions of informational technologies in prevention of organizational activity through operation measures and tactical actions]. Sostoyanie, problemy primenenniya i sovershenstvovaniya zakonodatel'stva o bor'be s organizovannoi prestupnost'yu i korrupstiey [State, problems of application and improving of legislation on fight against organized crime and corruption]. Moscow, 2000, 101 p.

18. Ovchinsky A.S., Mitrofanov E.A., Makarenkov D.E. Spetsial'nie tekhnicheskie sredstva i tekhnologii polucheniya operativnoy informatsii iz kanalov svyazi i kompyuternykh setey [Special technical means and technologies of obtaining of operative information from communication's channels and computers' nets]. Informatizatsiya pravookhranitel'nykh system [Information supporting of law enforcement system]. Moscow, 2000, 176 p. 
19. Ovchinsky S.S. Operativno-rozysknaya deyatel'nost' [Operation searching activity]: uchebnik/pod red. K.K. Goryainova, V.S. Ovchinskogo, A.M. Shumilova [textbook, ed. by K.K. Goryainov, V.S. Ovchinsky, A.M. Shumilov]. Moscow, 2001, 567 p.

20. Porubov N.I., Rahimov I.M., Suleymanov J.I. Taktika doprosa obvinyaemogo $\mathrm{v}$ konfliktnoy situatsii [Tactics of questioning of victim in conflict situation]. Baku, 1993, 106 p.

21. Solov'yev A.B. Protsessual'nye, psikhologicheskie i takticheskie osnovy doprosa na predvaritel'nom sledstvii [Procedural, psychological and tactical bases of interrogation in preliminary investigation]. Moscow, 2002, $192 \mathrm{p}$.

22. Suleymanov J.I., Shiraliyeva S.J. Problemy vzaimodeystviya sledovatelya i operativnykh rabotnikov pri rassledovanii prestupleniy. Uchebno-metodicheskoe posobie dlya sledovateley [Issues of interaction of investigator and operation officers at investigation of crimes. Methodic guidelines for investigators]. Baku, 2003, 255 p.

23. Usmanov U.A. Taktika doprosa [Interrogation tactics]. Moscow, 2001, 176 p. 